\title{
BUDAYA KEJUJURAN DALAM MENGHADAPI PERUBAHAN ZAMAN (Studi Fenomenologi Masyarakat Islam Modern)
}

\author{
Muhasim \\ STIT Palapa Nusantara Lombok-NTB \\ mhmsaidah@gmail.com
}

\begin{abstract}
The change of phenomenon is eternally and the change of epoch like a turn of seasons at the certain period of time, such as the change of days, months, years and centuries. Nowadays, we life in $21^{\text {st }}$ century or globalization era. It is indicated by the dramatic change. And it is also as the result of advance in science, digital revolution and the progress of transportation. This condition makes the world seems like to be so narrow, the turn of time feels so fast, the distance become closer. As the fact, today the long distance we can reach within hours and the information can be received very fast. This era's transformation has effect for somebody or society in his act and attitude. Such as the honesty damaging because of an importance, and somebody may act and pretend based on the condition. So that why, the focus of this discourse is to investigate the practice of honesty in globalization era. The method used in this research is descriptive method. In where, the understanding based on the object, the analyzing of various situation and social reality in society based on and the truth sources and some articles from online media which related with the object of this research. Hopefully, by this method can help to investigate, and analyze the honesty practice in the globalization era. Honesty has a moral value. It has influence to form a strong mentality in rising the competence and the hard worker, to face the globalization challenging in all job sectors. At the end, the honesty not only about the attitude, but also the dignity. The dignity and identity personally and nationally.
\end{abstract}

Keyword: Practice, Honesty, Globalization Era.

\begin{abstract}
Perubahan suatu fenomena yang bersifat abadi, dan zaman merupakan pergantian musim atau gejala dalam sebuah kurun waktu tertentu, seperti pergantian hari, bulan, tahun dan abad. Sekarang ini kita berada pada abad 21, dikenal dengan abad global, ditandai perubahan zaman yang sangat dramatis. Globalisasi sebagai akibat perkembangan ilmu pengetahuan, revulusi digital dan kemajuan transportasi. Karakteristik zaman tersebut, dunia seolah-olah menjadi semakin sempit, waktu menjadi sangat sulit dibedakan, jarak terasa semakin dekat,sekarang jarak yang jauh dapat ditempuh dalam hitungan jam, informasi pun dapat diterima dalam waktu sangat cepat.
\end{abstract}


Perubahan zaman itu dapat mempengaruhi perubahan sikap dan perilaku seseorang atau masyarakat, yang berakibat lunturnya budaya keujuran seseorang atau menjadi bersikap bohong, salah satu penyebab adalah faktor kepentingan, para pakar biasa menggunakan rumus sikap tergantung kepentingan. Olah karena itu fokus tulisan ini yaitu mengkaji bagaimana budaya kejujuran, menghadapi perubahan zaman. Metode yang digunakan adalah metode deskriptif, artinya memahami apa yang menjadi objek tulisan, mencermati berbagai situasi atau realitas sosial yang ada di masyarakat dari berbagai sumber yang dapat dipercaya, tulisan pada media online, yang berhubungan dengan objek tulisan.Dengan metode ini, dapat membantu dalam melakukan pengakjian, dan dapat dengan leluasa mencermati berbagai gejala budaya kejujuran di era perubahan zaman yang terus bergerak semakin cepat. Jujur mempunyai makna nilai moral yangdapat membentuk sikap mental yang kukuh untuk meningkatkan kompetensi dan pekerja keras, sehingga mampu menyesuaikan diri dengan perkembangan global diberbagai bidang pekerjaan. Pada akhirnya jujur bukan saja sikap, tetapi martabat,harga diri dan jati diri seseorang serta jati diri bangsa.

Kata Kunci : Budaya, Kejujuran, Perubahan Zaman

\section{Pendahuluan.}

Perubahan zaman yang terus bergulir semakin cepat, dan pasti memberikan pengaruh, baik positif maupun negatif. Perubahan adalah fenomena kehidupan manusia yang berjalan secara terus menerus dengan kata lain perubahan itu sifatnya abadi sepanjang waktu. Perubahan tidak akan bisa dihentikan dengan cara apapun, justru semakin berupaya kita hentikan, akan semakin banyak dampak yang terjadi, ibarat membendung banjir, akan menimbulkan banjir ditempat lain dan merusak.

Zaman, menggambarkan perbedaan yang terus berganti sebagai pengaruh perubahan, ibarat pergantian hari, bulan, tahun dan abad. Sekarang ini kita berada pada abad 21 disebut abad milenium ke tiga dalam kalender gregorian.Abad ini perubahan zaman meningkat secara dramatis, lazim disebut globalisasi. Abad 21 baru berjalan kurang lebih 17 tahun, akan berakhir di tahun 2099, kurang lebih lagi 83 tahun. Kita belum bisa memprediksi perubahan apa yang akan terjadi, jika kita tidak mempersiapkan diri, maka perubahan zaman itu bukan saja akan menjadi tantangan tetapi bencana. Menghadapi bencana itu semua masyarakat dituntut, siap budayakan kejujuran, karena budaya kejujuran yang diprediksi paling ampuh merubah perilaku manusia menghadapi perubahan zaman. Perubahan zaman dapat mempengaruhi perilaku seseorang, misalnya, gaya hidup mewah, kemajuan tehnologi informasi dan 
transpormasi, kekuasan dan kewenangan, jika ditangan orang tidak jujur, diduga menjadi virus perilaku kurang terpuji, antara lain penyalah gunaan kekuasaan, korupsi, kolusi, nepotisme, sogok suap, pungli, penipuan, dalam pelayanan publik.

Perilaku manusia sifatnya relatif, bisa kuat dan bisa berubah menjadi lemah bahkan perilaku seseorang bisa menjadi jahat, tidak beda dengan Iman seseorang, bisa kuat dan bahkan bisa hilang. Kejujuran cermin dari ketaqwaan seorang hamba yang beriman, sesuai Firman Allah” QS.At-Taubah (9): 119 “ Hai orang-orang yang beriman, bertaqwalah kepada Allah, dan hendaklah kamu bersama orang-orang yang benar".Jujur adalah satunya suara hati, ucapan dan perbuatan, dan pastilah tidak ada yang rela dikatakan bohong atau disamakan dengan perilaku hewan yang tidak memiliki akal dan pikiran. Jujur mencerminkan sikap hati yang menggambarkan ketaatan seseorang kepada Allah dan Rasul-Nya". ${ }^{1}$ Orang jujur pasti tetap patuh pada Allah dan menjalankan tuntutan Rasulullah Saw. Dari Ibnu Mas'ud ra, berkata :

Bersabda Rasulullah SAW, Orang jujur pasti tetap patuh pada Allah dan menjalankan tuntutan Rasulullah SAW. Dari Ibnu Mas'ud ra, berkata : Bersabda Rasulullah saw, "Wajib bagimu memegang teguh perkataan benar, karena perkataan benar membawa kebaikan, dan kebaikan mengajak ke surga". Seseorang yang senantiasa berkata benar, sehingga ditulis disisi Allah sebagai orang yang berbuat benar ( jujur ).Itulah pentingnya membudayakan kejujuran walaupun butuh proses belajar dan pembiasaan, agar bisa menjadi sebuah sistem kehidupan yang beradab. Kehidupan yang selalu taat terhadap Allah dan Rasul-Nya dan kehidupan para siddiki serta orang-orang saleh, bisa menjadi contoh yang sebaik-baiknya.

Perilaku jujur mencermin keimanan, etika dan moral seseorang, dia mengakui sang pencipta dan yakin akan pembalasan surga atas perbuatan baik dan neraka terhadap perilaku munkar. Dasar pemikiran terhadap pengakuan dan keyakinan terhadap sang Pencipta, menjadi pondasi membudayaan kejujuran terhadap sistem kehidupan masyarakat. Pemikiran tersebut menjadi kekuatan batin sesorang melahirkan perilaku yang penuh tanggung jawab, sesuai sabda Rasulullah Saw “ jauhi dusta, karena dusta akan membawa kepada dosa dan dosa membawamu ke neraka. Biasakanlah berkata jujur karena jujur akan membawamu kepada kebajikan dan membawamu ke surga".2

${ }^{1}$ Ahmad Hatta, Tafsir Qur'an Per Kata, Surat At-Taubah, (Jakarta: Magfirah Pustaka, Agustus 2010), 119.

${ }^{2}$ Toto Tasmara, Membudayakan Etos Kerja, (Jakarta: Gema Insani, 2002), 81. 
Ada beberapa pesan moral dapat kita petik dari uraian diatas, antara lain orang jujur menunjukkan sikap dan perbuatan selalu taat kepada Allah, mengikuti kaedah-kaedah agama, berbuat sesuai hati nurani/Iman, ucapan sesuai perbuatan, selalu berteman dengan orang-orang benar. Seorang manusia pasti memilih hidup dalam ketaatan kepada Sang Pencipta, tidak ada seorangpun rela dikatakan menyimpang dari perintah Allah. Semua manusia memilih kaedah Alqur'an menjadi penuntun dalam menjalankan perintah Allah, sesuai sumpahnya untuk beriman hanya kepada Allah, ketika ia diciptakan. Semua orang dalam hidup bermasyarakat, pasti menghendaki hidup jujur, dan tidak rela dikatakan berbohong.

Oleh karena itu pilihlah teman yang benar-benar berpegang pada kaedah alqur'an, seperti kata pepatah, anda berteman dengan penjual minyak wangi, anda pasti kecipratan wanginya, selin itu jika anda berteman dengan orang suka minumminuman memabukkan, sekali waktu anda akanterjebak dalam kehidupan hina itu. Teman yang benar adalah, teman yang ketika andaakan terjerumus kedalam jurang, dia menyelamatkan dengan menarik leher baju anda, bukan lantas mendorong anda jatuh kejurang.

Apa yang dipaparkan di atas, masih bersifat asumsi, artinya, apa yang diharapkan, belum tentu sama dengan kenyataan, kehidupan ini bukan tanpa ujian. Ada beberapa faktor yang dapat mempengaruhi kejujuran itu antara lain : manusia cendrung terjebak dengan berpikiran sempit yaitu ingin cepat mendapatkan sesuatu, tetapi tidak memikirkan akibat.Gaya hidup mewah, tidak sesuai kemampuan dengan kehendak,akhirnya terjadi penyimpangan seperti KKN dan pungli.Kebiasaan buruk seperti tidak disiplin alias suka mengentengkan, tidak menghargai nikmat kesehatan yang berikan,sudah stres baru sadar, kurang percaya diri sendiriartinya artinya tidak berpikir kreatif.

Kasus KKN (Korupsi, Kolusi dan Nepotisme), pungli terjadi, karena kejujuran tidak terkontrol. Seandainya kejujuran telah membudaya, tidak mungkin akan terjadi perilaku buruk itu. Berbuat benar merupakan sifat orang jujur, dimulai dari hati,ucapatan dan perbuatan. Mari kita bertanya pada diri sendiri, apakah ucapan sesuai hati nurani, apakah ucapan sesuai perbuatan. Mungkin apa yang penulis sampaikan ini bukan ukuran yang baku, tetapi minimal bisa diterima akal bahwabudaya kejujuran, menjadi kekuatan hadapi perubahan zaman. 
Akal miliknya manusia, yaitu satu-satunya mahluk diciptakan Allah SWT sebagai mahluk yang berakal. Itulah yang membedakan manusia dengan mahluk lain seperti hewan. Budaya merupakan produk manusia, sedang jujur merupakan kaedah atau norma agama dan memancar sebagai cermin nilai keimanan seseorang. Sesorang yang jujur pasti akan selalu berbuat benar, dan tidak mungkin terjerumus berbuat korup, kolusi dan nepotisme, bila ia terjerumus tentulah kejujurannya telah hilang.

Olah karenanyatujuan tulisan ini yaitu mengkaji makna budaya kejujuran, dan bagaimana membudayakan kejujuran untuk menghadapi perubahan zaman.

Metode yang digunakan adalah metode deskriptif, artinya memahami apa yang mejadi objek tulisan, mencermati berbagai situasi atau realitas sosial yang ada di masyarakat dari berbagai sumber yang dapat dipercaya, tulisan pada media online yang menjadi objek tulisan. ${ }^{3}$

\section{Ladasan Teori}

\section{BudayaKejujuran.}

Dasar berpikir yaitu QS. At-Taubah (9) “ Wahai Orang yang beriman bertakwalah kepada Allah dan berdalah kalian bersama orang-orang yang benar (jujur). Jujur sebagai cerminan dari keimanan dan tergolong orang-orang yang benar". ${ }^{4}$ Dalam QS. An-Nisa (4), "Siapa yang mentaati Allah dan Rasul (Muhammad SAW) maka mereka itu bersama orang-orang yang Allah memberi nikmat atas mereka dari para Nabi dan orang-orang yang sangat jujur “. ${ }^{5}$ Itulah gambaran yang akan Allah berikan kepada orang-orang yang jujur, bukankah nikmat Allah tidak dapat dihitung. Jika ditulis nikmat yang diterima manusia dengan air laut sebagai tintanya dan pohon sebanyak apa yang ada dibumi sebagai penanya, tidak akan bisa habis ditulis.

Bayangkan nikmat Iman yang demikian besar, jika dicabut oleh-Nya, manusia akan, kehilangan kendali dalam hidupnya didunia dan diakhirat pasti akan terlaknat. Nikmat kesehatan, silahkan direnungkan, jika menderita sakit gigi saja, tidak ada yang bisa dinikmati, makanan yang enak menjadi tidak enak, belum lagi sakit kangker ganas, gagal ginjal, serangan jantung, tidak akan bisa sembuh walaupun obat

\footnotetext{
${ }^{3}$ Burhan Bungin, Penelitian Kualitatif, (Bandung: Kencana Prenada Media Grouf, 2009), 68.

${ }^{4}$ Ibid., 69.

${ }^{5}$ Ibid., 119.
} 
secanggih apapun, kecuali Allah menyembuhkan. Secara jujur, sudahkan digunakan nikmat kesehatan itu, untuk beribadah, seperti kata orang bijak" shalatlah anda sebelum dishalatkan alias mati”.

Sadarkah manusia bahwa yang dibawa masuk keliang lahat adalah selembar kain putih, sedangkan kekayaan berupa harta, benda, mobil mewah, rumah bertingkat, anak tersayang, istri cantik hanya menangis diatas pusara anda. Manusia yang mati akan hanya besama do'a anak yang shaleh, amal jariah dan ilmu yang bermanfaat. Oleh karena itu " orang jujur selalu bertaqwa kepada Allah dan bersama orang-orang yang benar" At-Taubah ( 9) 119”. Orang jujur selalu berpegang pada Firman Allah dan petunjuk Rasul-Nya, dan itu akan melahirkan sikap yang penuh tanggung jawab, seakan -akan Allah melihatnya, sebagaimana firman Allah " Dan sungguh kami telah menciptakan manusia dan Kami (Allah) mengetahui apa yang dibisikkan oleh jiwa/hatinya dan Kami lebih dekat kepadanya dari pada urat lehernya"(QS. Qaaf). ${ }^{6}$

Pesan moral dari Firman Allah Swt. diatas menunjukkan bahwa jujur itu,jati diri manusia secara individual, sebagai mahluk ciptaan Allah Swt dan sebagai mahluk sosial. Jujur merupakan nilai atau norma agama sedangkan budaya merupakan produk manusia. Budaya berasal dari bahasa Sanskerta yaitu buddhayah, yang merupakan bentuk jamak dari buddhi (budi atau akal). Akal adalah miliknya manusia, yaitu satu-satunya mahluk diciptakan Allah SWT sebagai mahluk yang berakal. Jadi manusia selain sebagai mahluk ciptaan Tuhan, mahluk Individu juga mahluk sosial. Itulah yang membedakan manusia dengan mahluk lain seperti hewan. Hewan tidak memiliki akal, tidak sebagai mahluk berbudaya dan sosial. Dengan akal,budaya manusia berkembang, dari zaman tradisional sampai di zaman modern sekarang ini.

Dalam bahasa Inggris budaya disebut culture, yang berasal dari kata Latin Colere, yaitu mengolah atau mengerjakan. Bisa diartikan juga sebagai mengolah tanah atau bertani. Kata culture juga kadang diterjemahkan sebagai "kultur" dalam bahasa Indonesia. ${ }^{7}$ Menurut Edward Burnett Tylor, kebudayaan merupakan keseluruhan yang kompleks, yang di dalamnya terkandung pengetahuan, kepercayaan, kesenian, moral, hukum, adat istiadat, dan kemampuan-kemampuan lain yang didapat

${ }^{6}$ Toto Tasmara, Membudayakan., 145.

7 Ibid.,161. 
seseorang sebagai anggota masyarakat. ${ }^{8}$ Sedangkan menurut konsep yang dikemukakan oleh Freeman Butt dalam bukunya yang terkenal Cultural History of Western Education bahwa: “ Pendidikan adalah kegiatan menerima dan memberikan pengetahuan sehingga kebudayaan dapat diteruskan dari generasi ke generasi berikutnya."

Menurut Carter V.Goo, dalam Dictinary of Education bahwa pendidikan yang didalamnya terkandung pengetahuan mengandung pengertian:

1. Proses perkembangan kecakapan seseorang dalam bentuk sikap dan prilaku yang berlaku dalam masyarakatnya

2. Proses sosial dimana seseorang dipengaruhi oleh sesuatu lingkungan yang terpimpin (misalnya sekolah) sehingga ia dapat mencapai kecakapan sosial dan mengembangkan pribadinya. ${ }^{10}$

Jujur menurut H.Toto Tasmara,dalam bahasa arab berarti benar ( siddiq). "Kejujuran berarti menyampaikan kebenaran, ucapannya sesuai dengn kenyataan". ${ }^{11}$

Dalam bahasa Inggris kejujuran atau Integritas berasal daribahasa Latin integer, incorruptibility, " yaitu sikap yang teguhmempertahankan prinsip,tidak mau korupsi, dan menjadi dasar yang melekat pada diri sendiri sebagai nilai-nilai moral. Pengertian lain dalam bahasa Inggris Honest atau jujur, berasal dari bahasa Latin, honestus atau honos yang artinya terhormat atau menjadi terhormat. Honest diartikan juga dengan tidak pernah menipu, berbohong atau melawan hukum, Jujur atau tidak menyimpang dari prinsip kebenaran". ${ }^{2}$

Anas Salahudin M.Pd,berpendapat bahwa “ Jujur adalah perilaku pada upaya yang menjadikan dirinya sebagai orang yang selalu dapat dipercaya dalam perkataan,tindakan dan pekerjaan ". 13

\section{Perubahan Zaman.}

Islam sangat inten merespon perubahan di dunia ini, untuk menolong umat manusia dari kehidupan yang tidak berprikemanusiaan, tidak beda seperti hewan. Islam diciptakan untuk menolong manusia dalam menempuh kehidupan yang lebih

${ }^{8}$ http://balinessegirls.blogspot.co.id/2012/12/hubungan-adat-dengan-kebudayaan-dan.html(diakses 12 Maret 2017).

${ }^{9}$ https://pendidikandan kebudayaan. wordpress.com/, diakses 20 Maret 2017.

${ }^{10} \mathrm{http}: / /$ hadirukiyah.blogspot.co.id/2010/07/hubungan-kebudayaan-dengan-pendidikan.html, diakses, 1 April 2017.

${ }^{11}$ Ibid.

${ }^{12}$ Toto Tasmara, Membudayakan., 144.

13 Anas Salahudin dan Irwanto Alkriencienchi, Pendidikan Karakter, (Jakarta: CV Pustaka Setia, 2013). 43. 
modern, tetapi akhlak semakin buruk. Islam datang memberikan kehidupan semakin bermakna dalam menghadapi perubahan zaman yang bukan saja berepengaruh positif, juga negatif serta penuh tantangan bahkan ancaman. Perubahan itu tergantung pada manusia sendiri, sebagaimana firman Allah "Sesungguhnya Allah tidak akan merubah keadaan suatu kaum, sehingga mereka mengubah keadaan yang ada pada diri mereka sendiri’"14 (QS.Ar-Ra'ad:11).

Perubahan Zaman menunjukkan perbedaan dalam waktu tertentu dan ruang yang semakin tidak menentu. Misalkan zaman tradisional,sekarang ini zaman modern/ global. Perubahan zaman diera modernmenunjukkan perkembanganilmu pengetahuan, perkembangan tehnologi informasi, transpormasi, perkembangan industri yang menciptakan berbagai macam alat dan produk, yang dapat dipergunakan manusia untuk bekerja.

Seorang pemuda berseloroh dengan merespon perubahan yang positif, mengatakan "Alhamdulillah, Barat bisa menciptakan teknologi mutakhir, dan memproduksi temuan yang dapat membantu kita beribadah". Kenapa pemuda itu berkata demikian ? "tanya seseorang dengan heran, pemuda itu balik berkata" Ya, sebab Allah menciptakan kita sebagai umat yang terbaik (QS Ali 'Imran :110). Kenapa pemuda itu berkata demikian ? "tanya seseorang dengan heran, pemuda itu balik berkata" Ya, sebab Allah menciptakan kita sebagai umat yang terbaik ( QS Ali 'Imran :110).

Pengaruh negatif perubahan zaman,lunturnya nilai-nilai dan tradisi lama, mempengaruhi tingkah laku yang cenderung negatif, seperti korupsi, kolusi, demo, tawuran antarpelajar, perampokan dan terorisme. Perubahan gaya hidup menjadi bergaya hidup mewah,dan semangat belajar anak-anak menurun, sebab mereka cenderung melihat TV serta bermain Internet dengan berbagai acara dan film yang mempesona.

Sifat manusia cendrungmemilih pengaruh yang positif, karena tidak ada seorangpun yang mau celaka atau menyimpang dari perintah Allah atau menyengsarakan dirinya. Namun tidak boleh dilupakan bahwa sifat manusia yang lemah, lalai dan lupa, akan bisa melemahkan budaya kejujuran, bahkan hilang.

${ }^{14}$ Ahmad Hatta, Tafsir Qur'an Per Kata, Surat Ar-Ra'd: (11), 249. 
B. Simanjuntak, mengemukakan "Ketikamasyarakat merasakan kesulitan mencapai nilai yang hendak dicapai. Ketegangan yang paling berat dirasakan ialah harapan mencapai nilai lebih sedang nilai kesanggupan tidak memungkinkan”.Oleh karena itu mengetahui makna budaya kejujuran, serta membudayakan kejujuran menjadi hal yang sangat penting.

\section{Pembahasan.}

\section{Makna Budaya Kejujuran.}

Ada beberapa pesan moral didapat dari uraian diatas, bahwa budaya kejujuran, menunjukkan sikap seseorang memiliki prinsip yang jelas dan tegas, perbuatannya terkendali oleh hati yang paling dalam yaitu Iman atau aqidah. Dia mempertahankan harga diri, harkat dan martabatnya, dengan mengikuti perintah Allah dan petunjuk Rasulnya, meneladani perilaku para siddiqin, berteman dengan orang-orang saleh.

Jujur adalah kaedah atau norma, bersumber dari nilai- nilai agama khususnya agama Islam yang diyakininya. Jujur sebagaimana kaedah diatas masih bersifat abstrak, yang dapat dilihat adalah fenomena kejujuran yang mengandung ciri-ciri, yang nyata seperti berbuat sesuai perkataan, disiplin, berbuat yang benar, tidak menyimpang dari kaedah dan hukum. Makna keujuran bagi setiap orang itu cendrung bebeda, tergantung persepsi orang tentang budaya kejujuran. Jujur dalam bahasa adat Lombok yaitu maliq, artinya tidak boleh melakukan yang bertentangan dengan adat, jika dilakukan akan mendapat kutukan. Jujur bahasa arab "Siddiq", yang berati nyata, benar atau berkata benar, kesesuaian antara ucapan dan perbuatan, kesesuaian antara informasidan kenyataan.Sikap dan perilaku orang jujur, kembali kepada ketentuan Allah, seperti kata mutiara “ rizkimu bukanlah karena ikhtiar yang kamu lakukan, tetapi rizkimumerupakan pemberian Allah, sedangkan ikhtiar yang kamu lakukan tercatat sebagai ibadah.

Jujur, dalam bahasa Indonesia merupakan kata dasar dari kejujuran, menurut jenis katanya, jujur merupakan kata sifat sedangkan kejujuran merupakan kata benda. Menurut KBBI, kata "jujur" berarti lurus hati lawan katanya, tidak berbohong atau dusta. Budaya kejujuran, berbuat hanya karena Allah, maknanya perbuatan benar yang tidak dicampuri dengan kedustaan.Jujur melakukan apa yang diucapkan, 
persepsi lain dakwah bilhal, artinya bukan saja dakwah dengan metode ceramah, tetapi melakukan apa yang diceramahkan.

Banyak pihak mengadakan cemah didaerah yang terkenal dengan Seribu Masjid, dan dapat dipastikan selalu mengajak Istiqamah dalam menegakkan kebenaran sesuai perintah Allah dan Rasulnya. Displin dalam beibadah dan tekun bekerja, para da'i tersebut terdafar sebagai orang-orang yang ikut membudayakan kejujuran, tetapi tentang makna kejujuran, butuh pengakajian lebih mendalam. Budaya kejujuran, menurut pendapat K.H. Toto Tasmara, dalam Spiritual Centred Leaddership, mengemukakan bahwa kejujuran adalah ucapan dan perbuatan harus sama, dengan tetap berdasarkan kaedah agama.

Sikap jujur harusdiimplementasikan dalam satunya kata dengan perbuatan, bukan saja bisa mengucapkan tetapi ditunjukkan dalam perbuatan-perbuatan benar, sebagaimana pengertian jujur yang dalam bahasa arab "siddiq", pada landasan teori diatas. Implementasi dari budaya kejujuran yaitu perilaku yang berawal dari hati yang tulus, dipertimbangkan dengan akal dan pikiran yang benar. Jujur itu bersifat nilai, jadi setiap orang yang beragama, pasti merasa memiliki, baik diperoleh dengan belajar maupun yang diperoleh secara turun temurun dari leluluhur yang pantas dituruti, sebagaimana dikemukan oleh R. Linton, dalam landasan teori diatas.

Kejujuran tidak bisa dinilai semata-mata dari ucapan dan perbuatan, karena yang tahu diri,jujur atau dusta, yaitu diri sendiri dan Tuhan Yang Maha Kuasa. Kejujuran seseorang tidak bisa dinilai dari realitas perilaku, tetapi kejujuran seseorang hanya dalam persepsi bahwa orang yang berbuat benar dan berdasarkan kaedah dan tidak melanggar hukum tergolong orang jujur. Seseorang diprediksi termasuk orang jujur, jika ia disiplin beribadah tepat waktu, memanfaatkan umurnya untuk bershalat sebelum dishalatkan, memanfaatkan kesehatannya, sebelum ia struk, waspada dalam memilih teman, sebelum dikurung dalam kerangkeng jeruji besi.

Budaya kejujuran menjadi pondasi utama tegaknya nilai-nilai kebenaran, Allah Swt. berfirman dalam al-Qur'an yang Artinya: "Wahai orang-orang yang beriman! Bertakwalah kamu kepada Allah Swt. dan ucapkanlah perkataan yang benar.” (Q.S. al-Ahzāb/33:70) Orang jujur,perkataan sesuai dengan perbuatannya, karena termasuk dosa besar bagi orang-orang yang tidak mampu menyesuaikan perkataannya dengan perbuatan, atau lain dihati, lain ucapan, lain pula perbuatan. 
Allah SWT berfirman, "Wahai orang-orang yang beriman! Mengapa kamu mengatakan sesuatu yang tidak kalian lakukan? (Itu) Amat besar kemurkaan disisi Allah bahwa kalianmegatakan sesuatu yang tidak kalian lakukan.” (Q.S. ash-Shaff (61:2-3).QS.At-Taubah (9): 119, menegaskan "Wahai orang-orang yang mereka beriman bertaqwalah kalian kepada Allah dan beradalah kalian bersama orang-orang yang benar (jujur). Jujur sebagai cerminan dari keimanan dan tergolong orang2 yang benar”. Dalam QS. An-Nisa (4): 69, “ Dan siapa yang mentaati Allah dan Rasul (Muhammad), maka mereka itu akan bersama-sama dengan orang-orang yang diberikan nimat oleh Allah (yaitu) para Nabi, para pencinta kebenaran,orang-orang yang mati syahid dan orang-orang yang shaleh. Mereka itulah sebaik-baik teman.

Sungguh mulia pesan moral yang terkandung dari firman Allah diatas, bagi orang yang mampu melakukan hal tersebut, akan menjadikannya mulia dihadapan Tuhan-Nya, terhormat serta memiliki harga diri dimata sesama manusia. Tetapi ada saja orang, tidak dapat mengambil makna dari pesan moral tersebut, maka ia akan menjadi pembohong, koruptor, kolusi, nepotisme, sogok, suap dan pungli, akibatnya harga dirinya akan hilang. Budaya jujur dapat menghantarkan manusia menuju kesuksesan dunia dan akhirat. Pantaslah bagi manusia yang mempertahankan budaya kejujuran, orang itu telah membangunkan dirinya surga, ketika ia masih didunia.

Budaya kejujuran merupakan sikap yang tulus dalam melaksanakan sesuatu yang diamanatkan, baik itu berupa harta maupun tanggung jawab. Orang yang melaksanakan amanah disebut orang yang terpercaya, jujur, dan setia. Sikapnya tegas, tetap tegak dalam prinsip mengamankan amanah yang dipercayakan kepadanya, aman dan terjamin dari segala bentuk gangguan, baik gangguan yang datang dari dirinya sendiri maupun dari orang lain. Sifat jujur dan terpercaya merupakan sesuatu hal yang sangat penting dalam segala aspek kehidupan, seperti dalam kehidupan rumah tangga, perusahaan, perniagaan, politik,birokrasi dan hidup bermasyarakat. Sifat-sifat dan akhlak yang sangat terpuji, merupakan contoh yang diberikan Nabi Muhammad saw. dalam berjuang serta membangun masyarakat Islam. Salah satu sifatnya yang menonjol adalah kejujurannya sejak masa kecil sampai akhir hayat beliau, sehingga Ia mendapat gelar al-Amin. 
Menurut Imâm al-Ghazâlî ada enam tingkatan kejujuran. Orang yang mencapai derajat kejujuran yang sempurna layak disebut sebagai orang yang benar-benar jujur, antara lain:

"Pertama, jujur dalam perkataan, di setiap situasi, baik yang berkaitan dengan masa lalu, masa sekarang dan yang akan datang. Kedua, kejujuran dalam niat. Hanya karena Allah. Ketiga, kejujuran dalam bertekad. Seseorang bisa saja mempunyai tekad yang bulat untuk bersedekah bila dikaruniai rezeki. Juga bertekad untuk berbuat adil bila dikaruniai kekuasaan. Namun adakalanya tekad itu disertai dengan kebimbangan, tetapi juga merupakan kemauan bulat yang tanpa keragu-raguan. Orang yang mempunyai tekad yang bulat lagi kuat disebut sebagai orang yang benar-benar kuat dan jujur.Keempat, memenuhi tekad. Seringkali jiwa dibanjiri dengan kemauan yang kuat pada mulanya, tetapi ketika menginjak tahap pelaksanaan, bisa melemah. Karena janji tekad yang bulat itu mudah, namun menjadi berat ketika dalam pelaksanaan.Kelima, kejujuran dalam beramal. Tidak mengekspresikan hal-hal batin, kecuali batin itu sendiri memang demikian adanya. Artinya, perlu adanya keselarasan dan keseimbangan antara yang lahir dan yang batin. Keenam, kejujuran dalam maqammaqam agama. Ini adalah peringkat kejujuran tertinggi. Seperti maqam takut (khauf), harapan $\left(\right.$ raja $\left.^{\prime}\right)$, cinta $(\underline{b} u b)$, ridha, tawakal dan lain-lain. ${ }^{15}$

Pesan moral Imam al-Ghazali, mengandung makna yang sangat tinggi, bahwa manusia hidup didunia ini hanya sementara, dunia ibarat persinggahan, tempat menyiapkan bekal di akhirat,dimana rukh manusia hidup selamanya, sebelum ajal menjemput.Seseorang tidak masuk surga dengan amalnya, jika tidak ada Rakhmat Allah, amal ibadah manusia tidak bisa diandalkan, dibanding dengan nikmat yang sudah diterima. Oleh karena sepantasnyalah kita harus bekerja keras, semoga budaya kejujuran, selalu menjadi dasar dari setiap niat, ucapan dan perbuatan. Jika dapat demikian, maka budaya kejujuran telah bermakna bagi kehidupan dalam menghadapi perubahan zaman. .

Rasulullah Saw. adalah sosok yang jujur, itulah yang sesungguhnya menjadi contoh bagi setiap individu dan masyarakat. Coba bayangkan kalau setiap orang bebudaya jujur, maka koruptor, itu akan kabur dari bumi Indonesia. Korupsi, kolusi, pungli tidak bisa berjalan sendiri, minimal terdiri dari dua orang, ada transaksi saling memberi. Kalau boleh dikatakan sebenarnya rakyat sumber utama KKN, sogok, suap, dan pungli itu terjadi, kalau rakyat jujur, perbuatan laknat itu akan kabur dari bumi Indonesia.

15http://sufi-zone.blogspot.co.id/2010/03/imam-ghazali-ikhlas-dan-jujur.html, diakses 1 April 2017. 
Fenomena yang muncul, ada sinyalemen dalam penggunaan kekuasaan atau pelayanan publik “ kalau bisa dipersulit kenapa dipermudah”. Disatu sisi para pemegang amanah lupa bahwa dirinya adalah abdi atau budak rakyat, justru sebaliknya budak yang dilayani, kalau tidak dosogok, budak malas melayani. Dari kejadian itu diduga muncul niat dan perilaku tidak jujur,dari yang dilayani yaitu rakyat yang menjadi majikan, memberikan suap untuk mempercepat urusan, kemenangan tender proyek. Memberikan suap / melayani pungli untuk mempercepat pelayanan, bukankah ini sebuah fakta bahwa rakyatlah yang memulai KKN, suap dan pungli itu.

Nilai kejujuran itu, menunjukkan kualitas manusia, dengan itu manusia mengaktualisasi diri bertindak secara benar, berbicara yang benar dan melakukan pelayanan yang benar. Budaya kejujuran seseorang meliputi seluruh perilakunya, mulai dari sikap batin, ucapan dan perbuatan. Walaupun sulit kita mengetahui nilai kejujuran seseorang, karena sifatnya yang lebih interior dan mudah dimanipulasi. Keyakinan senantiasa menjadi tiang penyangga memperkuat budaya kejujuran seseorang, walaupun nilai kejujuran itu bisa lemah dan bisa kuat, tetapi bisa dikatakan membudayakan kejujuran adalah sebuah usaha untuk senantiasa bersikap selaras dengan nilai-nilai kebenaran serta sebuah usaha hidup secara bermoral dalam kebersamaan dengan orang lain.

Contoh kisah nyataseorang yang memahami makna budaya kejujuran. Kisahseorang pengembala kambing dengan Umar Bin Abdul Aziz, seorang pemimpin yang saleh. Umar meminta seekor kambing untuk dibeli dan akan dipotong, si anak pengembali menjawab, saya tidak punya Job deskription untuk menjual. Umar pun tetap mendesak, mana bisa bos mu tahu, jika ada seekor kambing dipotong, katakan saja dimakan serigala. Si anakpun merasa terdesak, dan akhirnya, dia berdiri dan berkata "Kalau demikian, di mana Allah, fa ainallah". ${ }^{16}$

Komisaris Motorola, diceritakan dalam buku Bob Galvin, mendapat kontrak 10 juta dollar untuk memasang sistem jaringan microwave disebuah Nugara di Amerika Selatan. Tetapi pembeli minta harga tersebut di mark up menjadi 11 juta dollar, mereka ingin menikmati kelebihan nilai kontrak. Apa sikap Motorola, ternyata motorola menolak untuk melanjutkan berbisnis lagi dengan negara tersebut sampai

16 Toto Tasman, Spritual Cabtered Leadership, (Jakarta: Gema Insani, 2006), 145. 
waktu yang tidak ditentukan. Motorola telah berlaku jujur, lebih menunjung tinggi harga diri, daripada kehilangan kontrak. Manusia memiliki harga diri, dalam pengertian spiritual, itulah yang membedakannya dengan mahluk lain seperti hewan.

Motorola telah memahami makna budaya kejujuran, dan ia mampu dan mau mengaplikasikan makna kejujuran itu, sebab ada orang yang mampu, tetapi tidak mau, ada juga orang yang mau tetapi tidak mampu, yang termasuk mendapatkan makna yaitu orang yang mampu dan mau melaksnakan budaya kejujuran itu. ${ }^{17}$

Kisah lain seorang hamba bernama Ulin, hamba mulia dan jujur, membeli tanah pada si Fulan. Ketika tanah itu digali, ternyata ditemukan sekeping emas. Lantas si Ulin mengembalikan sekeping emas itu pada si Fulan. Fulan bertanya mengapa engkau memberikan saya sekeping emas itu, Ulin mengatakan saya hanya membeli tanah, tidak membeli emasnya. Si Fulan tidak mau, karena dia merasa sudah menjual tanahnya pada si Ulin. Tidak terjadi kesepakatan antara si Fulan dan si Ulin, maka mereka bersepakat bertanya pada hakim yang adil, Hakim yang adil memberikan solusi, jual emas itu dan uangnya serahkan pada pakir miskin, akhirnya keduanya sepakat.

Alkisah hamba yang jujur diatas, bahwa budaya kejujuran itu, bagian dari sifat mulia dan benar manusia, budaya keujuran ibarat emas dan mutiara, ia benilai tinggi, oleh karena itu ia dicari walaupun terbenam dalam lumpur. Hilangnya budaya kejujuran, berarti tertutupnya kebenaran, harga diri dan kepercayaan orang akan hilang tertelan kegelapan, sulit akan dicari sampai ajal menjemput. Ibarat kata pepatah, hilang uang bisa dicari, kehilangan kejujuran dibawa sampai mati. Marilah kita mencari atau mempertahankan makna budaya kejujuran,minimal bagi diri sendiri, sebagaimana dicontohkan Rasulullah Saw.serta pengikut Rasulullah Saw yang telah mengenal makna kejujuran sebagaimana diungkapkan diatas.

\section{Bagaimana Membudayakan Kejujuran, Untuk Menghadapi Perubahan} Zaman.

Transfer nilai-nilai budaya dimiliki paling efektif adalah melalui proses pendidikan. Dalam masyarakat modern proses pendidikan tersebut didasarkan pada

17 Ibid., 147. 
program pendidikan secara formal. Di Indonesia UU Nomor : 20 Tahun 2003 , Satuan pendidikan adalah kelompok layanan pendidikan yang menyelenggarakan pendidikan pada jalur formal, nonformal, dan informal pada setiap jenjang dan jenis pendidikan. Pendidikan formal adalah jalur pendidikan yang terstruktur dan berjenjang yang terdiri atas pendidikan dasar, pendidikan menengah, dan pendidikan tinggi. Pendidikan nonformal adalah jalur pendidikan di luar pendidikan formal yang dapat dilaksanakan secara terstruktur dan berjenjang. Pendidikan informal adalah jalur pendidikan keluarga dan lingkungan.

Pendidikan termasuk unsur kebudayaan, oleh karena itu kebudayaan bukan statis, baku atau mutlak, tetapi kebudayaan berkembang seiring dengan perkembangan evolusi bathin maupun fisik manusia secara kolektif.Seperti dikemukakan Hasan Langgulung bahwa pendidikan mencakup dua kepentingan utama, yaitu pengembangan potensi individu dan pewarisan nilai-nilai budaya. Maka sudah jelas sekali bahwa kedua hal tersebut pendidikan dan kebudayaan berkaitan erat dengan pandangan hidup suatu masyarakat atau bangsa itu masing-masing, kedua hal tersebut tidak dapat dipisahkan karena saling membutuhkan antara satu sama lainnya.

Menurut Kamus Bahasa Indonesia, Pendidikan berasal dari kata "didik", Lalu kata ini mendapat awalan kata "me" sehingga menjadi "mendidik" artinya memelihara dan memberi latihan. ${ }^{18}$ Dalam memelihara dan memberi latihan diperlukan adanya ajaran, tuntutan dan pimpinan mengenai akhlakdan kecerdasan pikiran. Menurut Carter V.Goo, dalam Dictinary of Education bahwa mengandung pengertian kecakapan individu, dalam bentuk sikap dan perilaku dalam masyarakat. Perilaku masing-masing individu, dibentuk dalam lingkungan keluarga, pendidikan dan lingkungan sosial masyarakat.

Menurut konsep yang dikemukakan oleh Freeman Butt dalam bukunya yang terkenal Cultural History of Western Education bahwa:Pendidikan adalah kegiatan menerima dan memberikan pengetahuan sehingga kebudayaan dapat diteruskan dari generasi ke generasi berikutnya. Pendidikan adalah usaha yang dijalankan seseorang atau kelompok orang lain agar menjadi dewasa atau mencapai tingkat hidup atau penghidupan yang lebih tinggi dalam arti mental.

${ }^{18}$ Kamus Besar Bahasa Indonesia, tp, (Jakarta: 1991), 232. 
Menurut kaedah dikemukakan ilmuan diatas, dapat dipahami bahwa transformasi nilai-nilai budaya baik dalam bentuk kecakapan sikap maupun perilaku berproses secara individual, baru kemudian berkembang sebagai sebuah pengetahuan secara berkelanjutan dari satu generasi ke generasi selanjutnya. Kecakapan serta pengetahuan itu selain diperoleh melalui pendidikan formal, pengaruh lingkungan keluarga, masyarakat, memberikan andil cukup besar terhadap seseorang dalam mengembangkan diri, baik secara individual maupun dalam kehidupan bemasyarakat.

Manusia sebagai mahluk Individu, mahluk ciptaan Tuhan dan mahluk sosial. Sebagai mahluk ciptaan Tuhan, dia percaya dan yakin akan adanya sang pencipta dan dia mempercayai adanya kaidah-kaidah atau hukum yang wajib ditaati dalam mengatur hubungan dengan Tuhan- Nya dan mahluk lainnya. Manusia sebagai mahluk sosial memiliki adat istiadat sebagai dasar dari tata kelakuan dalam berhubungan dengan manusia lainnya.

Manusia dalam keseutuhannyaminimal menyandang dua dimensi yiatu sebagai mahluk yang berakal, dan mahluk yang berbudaya. Berkembangnya kebudayaan dengan kemampuan berpikir sebagai implementasi dari akal, manusia melalui proses berpikir mengolah potensi diri, maupun mengolah kekayaan alam yang diciptakan Allah. Model yang tepat yaitu melalui pendidikan. Pendidikan menjaga dan melestarikan kebudayaan itu sendiri, sekaligus sebagai media transfernilai-nilai budaya yang paling efektif. Keduanya sangat erat hubungannya karena saling melengkapi dan mendukung antara satu dengan lainnya. Melalui pendidikan terjadi sebuah proses transfer, pembaharuan, pelestarian dan peningkatan kebudayaan. Transfer nilai-nilai budaya leluhur yang masih layak dipertahankan, baik berupa adat istiadat, kesenian dan tingkah laku, serta memelihara benda-benda peninggalan yang menjadi bukti sejarah yang perlu dilestarikan.

Meningkatkan serta mempertahankan nilai-nilai moral, mungkin lebih akrab jika disebut membudayakan kejujuran. Nilai-nilai kejujuran menjadi benteng, agar manusia tidak terbawa arus pengaruh globalisasi yang negatif. Globalisai tidak saja berupa kemajuan kebudayaan manusia dibidang industri tehnologi komunikasi, transportasi dan industri lainnya, yang sifatnya positif, tetapi mampu mempengaruhi perilaku manusia bersifat negatif. Perilaku manusia dari zaman ke zaman berubah sangat cepat, seiring perubahan zaman. 
Dewasa ini, dunia seolah-olah menjadi semakin sempit, yang dulu ditempuh berbulan-bulan, sekarang dalam hitungan jam, seperti menunaikan ibadah haji. Perilaku hidup yang negatif, seperti pola hidup yang glamor, korupsi, kolusi, nepotisme, pungli, pesta miras, narkoba, seolah-olah tidak lagi menjadi rahasia umum, hal itu terjadi diduga karena lunturnya nilai kejujuran dan persepsi manusia tentang pertanggung jawaban manusia dihadapan Allah Swt Yang Maha Esa.

Pendapat diatas memperkuat pesepsi kita, pembudayaan kejujuran melalui dunia pendidikan sangat tepat. Ilmu Pengetahuan, keterampilan dan skill manusia, tidak berubah dengan sendirinya, tetapi melalui proses pendidikan, termasuk didalamnya kemampuan membaca. Rasulullah petama kali menerima wahyu dengan perintah membaca dalam surat Al-Alaq "Iqra" Bacalah dengan menyebut nama Tuhanmu yang Maha Pengasih”, ternyata sampai sekarang ajaran Rasulullah Saw, membudaya, langgeng dan berjaya. Artinya dengan membaca bisa melepaskan manusia dari kemiskinan, kebodohan dan keterbelakanan. Dunia luar seperti Amerika, Australia, Korea, Singapura, lebih maju, karena memang mereka mengembangkan kemampuan membaca, demikian ungkap Prof, Ir, Sunarpi., Ph.D, dalam seminar "Melalui Demokrasi Pendidikan untuk Meningkatkan Kualitas Sumber Daya Manusia”. Ketika memberikan ceramahnya di STIT Palapa Nusantara, Keruak Lombok Timur.

Penulis simpulkan bahwa kemampuan membaca bukan dalam pengertian sempit, tetapi manusia mampu membaca situasi sosial masyarakat, situasi dan kondisi keadilan serta kesejehteraan, termasuk bagaimana kualitas budaya kejujuran dalam penyelangaraan pemerintahan, pelayana publik, pembangunan dan pembinaan masyarakat. Bagaimana menghadapi perubahan zaman, dengan tingkat persaingan yang sangat ketat diberbagai bidang kehidupan, salah satu caranya adalah meningkatkan kompetensi sumber daya manusia, baik melalui pendidikan formal, non formal dan informal.

Institusi pendidikan merupakan lembaga sosial yang sangat menentukan kemajuan dan peradaban bangsa. Sulit dibayangkan, bangsa primitif, menjadi beradab dan bisa bersaing dengan bangsa lain jika tidak tanpa melalui pendidikan yang bermutu. Oleh karena itu pengelolaan pendidikan ke depan adalah perlunya reorientasi pendidikan, dengan menempatkan peserta didik menjadi subyek dari agen 
perubahan untuk membebaskan dirinya dari isolasi kemajuan tehnologi.Kemajuan teknologi akan sangat membantu, meski kita tidak dapat mengatakan bahwa komputerisasi akan memecahkan seluruh problem pendidikan. Belajar dengan bantuan komputer akan membuka wawasan yang sangat luas bukan saja dalam proses belajar, juga tentang konsep sekolah. Sekolah masa depan akan berubah sehingga akan lebih berupa "personalized learning center". Komputer akan banyak mengambil alih proses belajar hal-hal yangwajib, tugas sekolah atau guru akan beralih kepada memperkenalkan dan membangkitkan persepsi mengenai nilai-nilai.

Membudayakan kejujuranharus masuk menjadi agendapendidikan. Merujuk pendapat yang dikemukakan oleh Edward Burnett Tylor, kebudayaan merupakan keseluruhan yang kompleks, yang di dalamnya terkandung pengetahuan, kepercayaan, kesenian, moral, hukum, adat istiadat, dan kemampuan-kemampuan lain yang didapat seseorang sebagai anggota masyarakat.

Pendapat Edwar diatas, memberikan pandangan yang luas, bahwa jika kita berbicara masalah budaya maka lahan garapannya tidak saja dalam pengertian pendidikan formal, non formal dan informal. Media dakwah juga menjadi peluang untuk membudayakan kejujuran, sebagaimana kita maklumi rakyat Indonesia mayoritas memiliki keperyaan yang sangat kuat sesuai agama yang dianutnya. Agama Islam meletakkan kejujuran mengandung nilai yang sangat mahal, yaitu sebagai standar kualitas keimanan seseorang. Orang jujur selalau berbuat benar, dimana perilakunya atas perintah Allah dan Rasulnya, mentaati kaedah-kaedah agamanya, mengikuti perilaku para sahabat dan berteman dengan orang yang selalu berbuat benar.

Pendapat para pakar diatas, memberikan gambaran,bagaimana mempersipakan diri untuk meghadapi perubahan zaman yang akan terjadi. Perubahan zaman terus bergulir, tidak kenal kompromi, selaras dengan perputaran bumi, bulan dan matahari, sehingga kuncikesiagaan pada manusia sendiri. Bayangan bila perubahan zaman itu bukan saja merupakan hal yang menantang tetapi mengancam seluruh aspek kehidupan masyarakat. Maka wajib hukumnya manusia mempersiapkan diri untuk menghadapi, dalam kondisi senang atau susah. Syaratnya pendidikan nilai-nilai budaya kejujuran, harus diberikan, disemua jenjang pendidikan formal, non formal dan informal. 
Perubahan zaman yang menyebabkan globalisasi dengan penyebaran unsurunsur baru khususnya yang menyangkut informasi secara mendunia melalui media cetak dan elektronik. Demikian pula globalisasi menggambarkan hilangnya batas ruang dan waktu akibat kemajuan teknologi informasi.Bayangkan kalau sumber daya manusia, tidak mempersiapkan diri menghadapi perubahan yang terjadi, maka perubahan itu datang ibarat tsunami, menyapu bersih tenaga kerja yang tidak berkualitas, digantikan dengan tenaga kerja profesional dari negara-negara MEA. Akibatnya tenaga kerja setempat menjadi tamu di rumah sendiri, kalaupun bisa bekerja mungkin sebagai satpam, pembantu rumah tangga dan tukang kebun, ironis buka?

Mengantisipasi fenomena seperti itu, semua konponen baik Individu, pemerintah dan masyarakat, harus mempersiapkan diri melalui membudayakan kejujuran, karena berdasarkan nilai-nilai yang tertuang dalam firman Allah Swt, yang menjadi pondasi kajian dalam tulisan ini, mengisyaratkan, budaya kejujuran menyelamatkan manusia dari ujian baik berupa tantangan atau ancaman, tanpa itu manusia akan terlindas bahkan tertimbun perubahan zaman.

Jujur mempunyai makna nilai moral yaitu suatu pandangan batin yang bersifat mendarah daging. Dia merasakan bahwa hanya dengan bekerja benar, kreativitas akan tumbuh, etos kerja akan meningkat, disiplin dan kompetitif dalam segala pekerjaan. Kerenyanya,jujur bukansekedar kepribadian atau sikap,melainkan lebih mendalam lagi,dia adalah martabat,harga diri,jati diri seseorang dan motor penggerak kreativitas..

Di dalam jiwa seseorang yang jujur itu terdapat komponen nilai ruhani yang membetulkan berbagai sikap yang berpihak kepada kebenaran dan berbudi pekerti yang terpuji. Dari Abu Hurairah ra, ia berkata: " yang paling banyak di antara orang yang masuk surga itu ialah orang yang bertaqwa dan baik budi pekertinya”. Seseorang yang telah dibelenggu,diperbudak,dikuasai oleh kejujuran, dia merasa bangga menjadi budaknya Allah, dia merasa merdeka kerena terpenjara oleh kejujuran. Tindakan yang menyimpang dari nilai ruhani kejujurannya itu berarti dia telah menghianati diri dan keyakinannya sendiri. Orang yang tidak jujur berarti menipu dirinya sendiri di hadapan Allah SWT. Orang yang menjadikan kejujuran sebagi kebutuhan,akan menempatkan dirinya dalam tingkat kemuliaan. Kejujuran adalah kunci surga, jauhilah dusta karena dusta akan membawa kepada dosa dan dosa membawa 
keneraka. Biasalah berkata jujur karena jujur akan membawa kepada kebaikan dan membawa ke surga.

Kejujuran tidak datang dari luar,tetapi bisikan kalbu yang secara terus menerus mengetuk-ngetuk dan membisikkan nilai moral luhur yang didorong gelora cinta yang meng-ilahi. Kejujuran bukan sebuah keterpaksaan,melainkan sebuah panggilan dari dalam,sebuah keterikatan, Commitment,aqad,I'tiqad. Kisdarto Atmosoeprapto mantan Dirut PT.Perkebunan XX, dalam Etos Kerja Islam menulis" Tidak jujur dan kata-katanya tidak bisa dipegang berari tidak bisa dipercaya. Jujur,tetapi tidak mempunyai integritas berarti tidak bisa diandalkan. Mempunyai integritas,tetapi tidak jujur berarti diragukan iktikadnya.Tetapi ujur dan mempunyai integritas menjadikan dirinya sebagai panutan.Artinya bahwa jika budaya kejujuran sebagai variabel bebas, dan budaya kejujuran luntur, maka tidak bisa dibayangkan perubahan zaman, selain tidak bisa bermanfaat bagi manusia, juga menjadi ancaman kehidupan manusia.

Perkembangan budaya manusia dari zaman kezaman semakin hebat yang disimbulkan dengan globalisasi. Contoh sekarang HP (Hand Phone) bukan sudah menjelajah kedesa-desa, Ibu-ibu yang pemdidikannya tidak tamat SD, suaminya bekerja di Negeri jiran sudah memegang HP, anak-anak dari setingkat SD, SMP, generasi muda putus sekolah, sudah berInternet lewat HP nya, belum lagi media elektronik TV yang menjamur, juga menayangkan berbagai informasi, Sinetron, Film Barat, begitu juga berbagai model pakaian, rambut. yang kurang cocok dengan budaya Bangsa. Hal itu berdampak pada perubahan perilaku, tidak konsentrasi bahkan terjadi penyimpangan perilaku ketidak jujuran, dalam hal ini kita tidak menyalahkan siapa-siapa, yang salah adalah sistem dan kemauan serta kemampuan untuk mengimbangi perubah yang terjadi.

Pengaruh negatif, gaya hidup mewah, muncul sebagai masa kini masyarakat, satu sisi tidak sesuai dengan kemampuan, ibarat kata pepatah lebih besar pasak daripada tiang, menjadi biang kerok penyimpangan perilaku jujur seperti korup, kolusi, nepotisme, penyalah gunaan kewenangan, bagi yang memiliki kewenangan.

Jika demikian halnya, maka untuk membudayakan kejujuran, dimulai masingmasing individu harus siap berubah, begitu juga pern dunia pendidikan,sangat penting dan paling efktif,menjadi media membudayakan kejujuran dalam menghadapi 
perubahan zaman. Perubahan zaman menjadi satu kesatuan dengan budaya, pendidikan dan nilai-nilai kejujuran, karena itu perubahan budaya kejujuran minimal harus seimbang, idealnya harus lebih kuat budaya kejujuran daripada perubahan zaman, sehingga perubahanzaman dalam berbagai bentuknya dapatdimanfaatkan manusia.

\section{Catatan Akhir}

Pengaruh perubahan zaman terus bergulir semakin cepat, dan mempengaruhi paradigma berpikir dan beperilaku kehidupan bermasyarakat. Paradigma zaman,mempengaruhi cara berpikir dan perilaku seseorang, mempengaruhi gaya hidup mewah, perilaku berkomnikasi, berpakaian, model rambut, gaya bicara, mengunakan kekuasaan, kewenangan, sogok, pungli, konon pengaruh perubahan zaman. Jika perubahan zaman menjadi kembing hitam, maka budaya kejujuran yang berimplikasi pada peningkatan kompetensi sumber daya manusia dan tenaga kerja khususnya, menjadi sebuah keharusan.

Kita tidak bisa memponis orang itu jujur atau bohong, karena budaya kejujuran , bisa bisa kuat dan bisa berubah menjadi lemah dan jahat. Dalam laut dapat diukur, dalam hati siapa tahu, Wallohualam bissawab hanya Allah yang bisa menghakimi. Tetapi semoga apa yang kita lihat, tampak dalam ucapan sama dengan dihati dan perilaku yang bisa kita amati. Budaya kejujuran cermin dari ketaqwaan seorang hamba yang beriman, sesuai Firman Allah" QS.At-Taubah (9): 119 "Hai orang-orang yang beriman, bertaqwalah kepada Allah, dan hendaklah kamu bersama orang-orang yang benar". Pastilah tidak ada yang rela dikatakan bohong atau disamakan dengan perilaku hewan yang tidak memiliki akal dan pikiran.

Makna budaya kejujuran bagi setiap orang itu bisa saja bebeda, tergantung pemahaman orang tentang budaya kejujuran. Jujur bahasa arab " Siddiq “, yang berati nyata, benar atau berkata benar, kesesuaian antara ucapan dan perbuatan, kesesuaian antara informasidan kenyataan. Sikap dan perilaku orang jujur, dan ikhlas menerima pemberian Allah, seperti kaedah yang mengatakan “ rizkimu bukanlah karena ikhtiar yang kamu lakukan, tetapi rizkimu merupakan pemberian Allah, sedangkan ikhtiar yang kamu mlakukan tercatat sebagai ibadahmu.

Pada perubahan zaman ini masih terdapat kehidupan masyarakat, berada dalam kebodohan, oleh karena itu membudayakan kejujuran merupakan keharusan 
tetapi kewjiban setiap orang.Oleh karena itu syukurkan pendidikan dalam arti luas tetap berjalan, kehidupan berdasarkan aqidah dan adat istiadat terus terbina, sehingga diharapkan membudayakan kejujuran untuk menghadapi perubahan zaman, berjalan secara otomatis.

\section{Daftar Rujukan}

Adig Suwandi dkk, Padoksi Perubahan, Penerbit, Yayasan SEYMA MEDIA, Malang, 2004.

Anas Salahudin Drs,M.Pd, Pendidikan Karakter, Penerbit, CV. Pustaka Setia, Bandung, 2013.

Burhan Bungin,Prof.Dr.H.M, S.Sos. M.Si., Penelitian Kualitatif, Penerbit,Kencana Prenada Media Group,Jakarta, 2007.

B.Simanjuntak,Drs.S.H, Perubahan dan Perencanaan Sosial ,Penerbit TARSITO, Bandung, 1981 .

K.H.Toto Tasmara, Membudayakan Etos Kerja Islami, Penerbit, Gema Insani Press, Jakarta, 1987.

K.H.Toto Tasmara, Spiritual Centered Leadership,Penerbit, Gema Insani, Jakarta, 2006.

http://pks.psikologi.unair.ac.id/coretan-kami/membangun-peradaban-bangsadengan-pendidikan-berkarakter-moral/

https:// cakslamet.blogspot.co.id/2012/03/nilai-kejujuran-dalam-pendidikan.html https://boeyberusahasabar.wordpress.com/2013/12/10/rakyat-penentupemberantasan-korupsi/

https:// dinamikagurusd.blogspot.co.id/2014/04/pendidikan-karakter-kejujuransebagai.html

http://kisahimuslim.blogspot.co.id/2014/90/contoh-buki-kejujuran-nabimuhammad-saw.hml.

http://kisahimuslim.blogspot.co.id/2014/09/arti-dan-makna-kejujuran-dalam islam.html.

https://garudabukateja.blogspot.co.id/2015/08/makna-kejujuran.html

http://aceh.tribunnews.com/2014/05/02/makna-sebuah-kejujuran

https://kasihimuslim.blogspot.co.id/2014/08/petaka kebohongan.html.subscibe via RSS

http://sufi-zone.blogspot.co.id/2010/03/imam-ghazali-ikhlas-dan-jujur.html

http://ulfa99azzahra.blogspot.co.id/2015/01/hubungan-konsep-nilai-moral-dannorma.html.

https://kudusantikorupsi.wordpress.com/tag/nilai-nilai-kejujuran/

https://medipribadi.wordpress.com/ 